\title{
Penilaian Gangguan Perilaku Anak Talasemia Mayor dengan Menggunakan The Child Behavior Checklist
}

Mire Riyana, Muhammad Riza

Departemen Ilmu Kesehatan Anak Fakultas Kedokteran Universitas Sebelas Maret/RSUD Dr. Moewardi, Surakarta

Latar belakang. Masalah gangguan perilaku anak yang menderita talasemia mayor, antara lain, masalah perkembangan, lingkungan sekolah, keluarga, dan masyarakat. Penilaian untuk menilai gangguan perilaku internal atau eksternal anak talasemia mayor perlu dilakukan.

Tujuan. Menilai gangguan perilaku anak talasemia mayor dengan menggunakan the child behavior checklist (CBCL).

Metode. Penelitian ini merupakan studi deskriptif. Populasi adalah anak penyandang talasemia mayor yang berusia 6 sampai 18 tahun yang dirawat di bangsal talasemia Rumah Sakit Dr. Moewardi Surakarta antara bulan Desember 2016 - April 2017 dengan diberikan kuesioner CBCL.

Hasil. Didapatkan gangguan perilaku internal 22 anak $(73,3 \%)$ dalam kategori terganggu dan gangguan perilaku eksternal dalam kategori normal 12 anak $(40,0 \%)$ dari 30 anak populasi talasemia mayor. Rerata usia 12,62 $\pm 3,20$ tahun dengan usia 6-11 tahun 9 $(30,0 \%)$ anak, dan usia $12-18$ tahun $21(70,0 \%)$ anak.

Kesimpulan. Terdapat gangguan perilaku pada anak talasemia mayor. Didapatkan sebagian besar anak dengan gangguan perilaku internal, sementara sebagian besar anak dengan perilaku eksternal dalam kategori normal. Usia anak yang lebih tua memiliki skor CBCL lebih tinggi dan memiliki lebih banyak masalah perilaku. Sari Pediatri 2017;19(3):127-30

Kata kunci: talasemia mayor, gangguan perilaku, CBCL

\section{Applying the Child Behavior Checklist to Examine Thalassemia Children Behavior Disorder}

Mire Riyana, Muhammad Riza

Background. Behavior disorder in children who experience severe sickness of major thalassemia may indicate symptoms like lack of mental development that might occur at school, family, and surroundings. A child with major thalassemia is necessarily examined to investigate how far thalassemia can affect behaviors in both internal and external.

Objectives. To elicit the behavior disorder in thalassemia children in their internal and external conduct based on CBCL (Child Behavior Checklist)

Methods. This research was descriptive study by examining thalassemia children aged 6 to 18 years old. These children had medical treatments at Dr. Moewardi Surakarta in children ward from Desember 2016 - April 2017 and CBCL questionnaire was used as the instrument.

Result. From the 30 population of thalassemia children, it was discovered that 22 children (73.3\%) had internal behavior disorder whilst only 12 children (40\%) which was considered as normal group, experiencing external behavior disorder. The average age for the children in this study is $12,62 \pm 3,20$ years old, with 9 of them were $6-11$ years old $(30,0 \%)$, and 21 of them were $12-18$ years old $(70,0 \%)$.

Conclusion. Behavior disorder does exist in major thalassemia children. It is found that the majority behavior disorder take place in internal behavior while the external behavior disorder is in normal category. In addition, older children have higher CBCL score and more other behavior problems. Sari Pediatri 2017;19(3):127-30

Keywords : major thalassemia, behavior disorder, CBCL

Alamat korespondensi: Dr. Mire Riyana. Departemen Ilmu Kesehatan Anak Fakultas Kedokteran Universitas Sebelas Maret/RSUD Dr. Moewardi, Surakarta. Email: mireriyana@gmail.com 
Mire Riyana dkk: Penilaian gangguan perilaku anak talasemia mayor dengan menggunakan CBCL

$\mathrm{T}$ alasemia adalah kelainan genetik yang disebabkan oleh mutasi pada gen yang mengkode produksi rantai globin $\alpha$ (talasemia $\alpha$ ) dan globin $\beta$ (talasemia $\beta$ ) dengan manifestasi utama yaitu anemia hemolitik yang progresif. Prevalensi talasemia yang tinggi ditemukan di Afrika, Mediterania, Asia Selatan, dan Asia Tenggara. ${ }^{1}$ Indonesia berada dalam kawasan ini yang disebut sebagai kawasan sabuk talasemia (talasemia belt region) dengan prevalensi talasemia beta mayor yang tinggi. ${ }^{1,2}$

Derajat keparahan talasemia beta dibedakan menjadi talasemia beta mayor (paling berat dan membutuhkan transfusi darah secara periodik seumur hidup), talasemia beta intermedia, dan talasemia beta minor (paling ringan). Klasifikasi ini memiliki implikasi klinis dalam diagnosis dan tata laksana. ${ }^{2}$ Pemberian transfusi secara teratur dan terapi kelasi besi dapat meningkatkan angka harapan hidup penderita talasemia beta mayor. Namun, peningkatan harapan hidup ini juga dihubungkan dengan komplikasi berbagai sistem organ yang disebabkan oleh anemia kronik, efek kelebihan besi pada jaringan, efek samping agen kelasi, infeksi akibat transfusi. Anak dengan talasemia perlu dilakukan penilaian untuk menilai sejauh mana kondisi sakit kronis yang memberikan pengaruh dalam menurunkan kualitas hidup. ${ }^{3,4}$

Kondisi sakit di masa kecil pada anak dengan penyakit kronis memiliki komplikasi untuk terjadinya gangguan fungsional, psikososial, dan memengaruhi dinamika dalam keluarga. Perilaku anak yang menderita sakit kronis juga memberikan pengaruh tersendiri terhadap manajemen kesehatan dalam keluarga. Anak yang menderita talasemia mayor merupakan beban yang sangat berat menyebabkan orang tua merasa sedih, kecewa, putus asa, stres, bahkan depresi. Keadaan anemia yang berat menyebabkan anak memiliki keterbatasan dalam beraktivitas, keterampilan dan daya ingat, anak mudah merasa lelah, dan sulit melakukan kegiatan yang seharusnya mampu dilakukan anak seusianya. Pada beberapa penelitian disebutkan bahwa anak dengan penyakit kronis memiliki masalah dengan keluarga serta lingkungan disekitar tempat anak berinteraksi. ${ }^{3,4}$

Penelitian dilakukan untuk menilai sejauh mana kondisi sakit kronis anak talasemia mayor dapat terjadi gangguan perilaku internal dan eksternal dengan menggunakan the child behavior checklist (CBCL). ${ }^{3,4}$

\section{Metode}

Penelitian ini merupakan studi deskriptif yang Diatas Populasi sasaran adalah pasien anak dengan talasemia mayor yang berusia 6 sampai 18 tahun yang dirawat di Bangsal Anak Talasemia Rumah Sakit Dr. Moewardi Surakarta antara bulan Desember 2016 - April 2017. Subjek penelitian yang memenuhi kriteria dimasukkan dalam sampel penelitian secara konsekutif. Subjek penelitian diambil sesuai dengan kriteria inklusi dan eksklusi. Kriteria inklusi adalah anak talasemia usia 6 sampai 18 tahun yang dirawat di bangsal anak talasemia Rumah Sakit Dr. Moewardi antara bulan Desember 2016 sampai dengan April 2017, anak talasemia lakilaki dan perempuan, anak talasemia pasien lama atau pasien kontrol dan orang tua atau wali menandatangani informed consent penelitian. Kriteria eksklusi adalah pasien diketahui memiliki penyakit lain selain talasemia, seperti gangguan neurologis dan penyakit jantung bawaan. Subjek dibagi menjadi dua kelompok, yaitu gangguan internalisasi (masalah emosional, masalah kecemasan, dan masalah somatik) dan eksternalisasi (perilaku agresif dan kenakalan anak).

\section{Hasil}

Berdasarkan Tabel 1 diketahui bahwa pasien mayoritas dengan jenis kelamin perempuan 17 anak, sedangkan sisanya laki-laki. Rerata usia anak 12,62+3,20 tahun

Tabel 1. Karateristik pasien

\begin{tabular}{lcc}
\hline Variabel & $\mathrm{n}$ & Rerata \pm SD \\
\hline Jenis kelamin & & \\
$\quad$ Perempuan & 17 & \\
$\quad$ Laki-laki & 13 & \\
Usia (tahun) & & $12,62 \pm 3,20$ \\
$\quad 6-11$ & 9 & \\
$12-18$ & 21 & \\
Pendidikan & & \\
Tidak sekolah & 1 & \\
SD & 13 & \\
SMP & 9 & \\
SMA & 6 & \\
Status ekonomi & & \\
> UMK & 11 & \\
<_UMK & 19 & \\
\hline
\end{tabular}

UMK : upah minimum kabupaten/kota 
Mire Riyana dkk: Penilaian gangguan perilaku anak talasemia mayor dengan menggunakan CBCL

Tabel 2. Gambaran gangguan perilaku internal dan eksternal

\begin{tabular}{|c|c|c|c|c|c|}
\hline \multirow[t]{2}{*}{ Gangguan perilaku } & \multicolumn{2}{|c|}{ Internal } & \multirow{2}{*}{$\begin{array}{l}\text { Gangguan } \\
\text { perilaku }\end{array}$} & \multicolumn{2}{|c|}{ Eksternal } \\
\hline & $\mathrm{n}$ & $\%$ & & $\mathrm{n}$ & $\%$ \\
\hline Normal & 5 & 16,7 & Normal & 12 & 40,0 \\
\hline Rata-rata & 3 & 10,0 & Borderline & 11 & 36,7 \\
\hline Terganggu & 22 & 73,3 & Terganggu & 7 & 23,3 \\
\hline Total & 30 & 100 & Total & 30 & 100 \\
\hline
\end{tabular}

dengan usia 6-11 tahun 9 anak dan mayoritas pasien dengan usia 12-18 tahun 21 anak. Berdasarkan tingkat pendidikan, tidak sekolah 1, SD 13, SMP 9, dan SMA 6 anak. Tingkat ekonomi keluarga mayoritas di bawah sama dengan UMK, yaitu 19 anak, dan yang di atas UMK 11 anak.

Berdasarkan Tabel 2 diketahui bahwa terdapat 5 anak dengan gangguan perilaku internal dalam kategori normal, 3 dengan gangguan perilaku internal, 3 dalam kategori borderline, dan 22 anak dengan gangguan perilaku internal dalam kategori terganggu. Jadi sebagian besar anak dengan perilaku internal dalam kategori terganggu.

Terdapat 12 anak dengan gangguan perilaku eksternal dalam kategori normal, sedangkan eksternal dalam kategori borderline 11 anak, eksternal dalam kategori terganggu 7 anak. Jadi sebagian besar anak dengan perilaku eksternal dalam kategori normal.

\section{Pembahasan}

Gangguan perilaku pada anak dikelompokkan dalam dua kelompok, yaitu eksternalisasi dan internalisasi. Gangguan eksternalisasi ditandai dengan perilaku yang diarahkan ke luar diri. Gangguan internalisasi ditandai dengan pengalaman dan perilaku yang lebih terfokus ke dalam diri. Selanjutnya, diperoleh skor internalisasi (withdrawn, somatic complaints dan anxious/depressed) dan skor eksternalisasi (aggression behavior, delinguency behavior ). ${ }^{6,7}$

Subjek yang memenuhi kriteria diberi kuesioner the child behavior checklist (CBCL), terdiri atas 113 pertanyaan yang dibagi 8 skala subklinikal, yaitu withdrawn behaviour, somatic complaints dan anxious/ depressed, social problems, thought problems, attention problems, delinquency behavior, aggression behavior.

Kelompok eksternalisasi dan internalisasi dibagi tiga, yaitu normal, borderline, dan terganggu. Daftar pemeriksaan menggunakan CBCL yang terdiri dari sejumlah pertanyaan tentang perilaku anak. Tanggapan dicatat pada skala $0=$ tidak benar, $1=$ kadang-kadang benar, 2 = sangat benar atau sering benar. Pertanyaan serupa dikelompokkan ke dalam sejumlah sindrom. Beberapa sindrom dijumlahkan untuk memberikan skor untuk internalisasi dan eksternalisasi skala masalah. ${ }^{6}$

Rerata usia anak talasemia mayor $12,62 \pm 3,20$ tahun, dengan usia 6-11 tahun $9(30,0 \%)$ anak, dan mayoritas pasien dengan usia 12-18 tahun 21 $(70,0 \%)$ anak. Gambaran gangguan perilaku internal didapatkan $22(73,3 \%)$ anak dalam kategori terganggu. Gambaran gangguan perilaku eksternal didapatkan 12 $(36,7 \%)$ anak dalam kategori normal. Hasil tersebut sesuai dengan studi selama 25 tahun terakhir yang telah menunjukkan bahwa prevalensi gangguan perilaku pada anak talasemia berkisar 23\%-80\%. Gangguan psikologis ini memengaruhi kepatuhan terhadap pengobatan talasemia. Dalam studi ini, ditemukan bahwa 32\% dari anak talasemia memiliki skor total CBCL klinis abnormal. ${ }^{5}$

Child behavior checklist merupakan alat penilaian terhadap gangguan internalisasi (masalah emosional, masalah kecemasan, dan masalah somatik) dan eksternalisasi (perilaku agresif dan kenakalan anak). Penelitian oleh Hongally $\mathrm{dkk}^{5}$ di India ditemukan bahwa $32 \%$ anak talasemia memiliki skor total CBCL tinggi klinis yang abnormal. Hal tersebut mengindikasikan keberadaan masalah perilaku di dalamnya. Skor masalah CBCL internalisasi terlihat pada 34\% anak yang menunjukkan gejala penarikan sosial, keluhan somatik, dan kecemasan / depresi. Skor CBCL eksternalisasi terlihat pada 30\% anak yang menunjukkan gejala perilaku agresif. Dalam penelitian ini ditemukan bahwa anak yang lebih tua usianya memiliki skor CBCL lebih tinggi dan memiliki lebih banyak masalah perilaku. ${ }^{5}$

Masalah perkembangan selain disebabkan karena penimbunan besi juga dipengaruhi oleh usia dan jenis kelamin, tiap-tiap tahap perkembangan mempunyai 
ciri tersendiri. Usia terbagi 4 tahap, masa pranatal, masa bayi, masa pra-sekolah, dan masa sekolah. Pada masa sekolah, masaremaja dibagi lagi berdasarkan usia dan jenis kelamin karena perkembangan pada masa remaja dipengaruhi juga dengan status pubertasnya. Sesungguhnya, tiap-tiap tahap tumbuh kembang tersebut tidak terdapat batas yang jelas karena proses tumbuh kembang berjalan secara berkesinambungan. ${ }^{8,9}$

Anak penyandang talasemia mayor akan bermasalah dalam lingkungan sekolah karena transfusi berulang menyebabkan anak sering tidak masuk sekolah sehingga absensi sekolah meningkat. Hal tersebut memengaruhi ganguan perilaku eksternal. Keadaan anemia menyebabkan keterbatasan aktifitas anak, keterampilan dan daya ingat menurun, anak mudah merasa lelah, dan sulit melakukan kegiatan yang seharusnya mampu dilakukan anak seusianya. Ketergantungan pada orangtua dan minta perhatian lebih adalah ukuran penting untuk aspek emosional. Akibatnya, kualitas hidup menurun dan dapat menyebabkan gangguan perilaku. ${ }^{10}$

\section{Kesimpulan}

Penilaian gangguan perilaku pada anak talasemia mayor dengan menggunakan CBCL didapatkan sebagian besar anak dengan gangguan perilaku internal sementara sebagian besar anak dengan perilaku ekternal dalam kategori normal. Anak yang lebih tua usianya memiliki skor CBCL lebih tinggi dan memiliki lebih banyak masalah perilaku.

\section{Daftar pustaka}

1. Mohamad H, Yasser W, Muneer H, Alshahrani, Azzah A, Alhijji. Regional consensus opinion for the management of Beta Thalassmia major in the Arabian Gulf area. Orphanet J Rare Dis 2013;8:143.

2. David W. The Thalassemias: the role of molecular genetics in an evolviong global health problem. Am J Hum Gent 2004;74:385-92.

3. Lanzkowsky P. Thalassemias. Dalam: Manual of pediatric hematology and oncology. Edisi ke-5. Philadelphia: Elsevier; 2011.h.231-45.

4. Hasan R, Alatas H. Thalassemia. Dalam: Buku kuliah 1 ilmu kesehatan anak. Jakarta: Fakultas Kedokteran Universitas Indonesia; 2002.h.419-50.

5. Hongally C, Benakappa A, Reena S. Study behavioral problems in multi transfused thalassemic children. Indian J Psychiatry 2012;54:333-6.

6. Hockenberry M. Wong's essentials of pediatric nursing. Edisi pertama. New York: Mosby; 2009.

7. Kenneth H, Robert J, Julie C. Social withdrawal in childhood. Annu Rev Psychol 2009;60:141-7.

8. Shaligram D, Girimaji S, Chaturvedi S. Psychological problems and quality of life in children with thalassemia. Indian J Pediatr 2007;74:727-30.

9. Soetjiningsih. Tumbuh kembang anak. Dalam: Gde Ranuh I, penyunting. Buku tumbuh kembang anak. Edisi ke-2. Jakarta: EGC; 2013.h.1-36.

10. Kaarina L, Jatta A. Withdrawn children is risks of exclusion from social interaction. Diunduh pada 23 Oktober 2017. Didapat dari: http://www.leeds.ac.ukleducol/documents/00003747.htm. 